\title{
Circulation of oxytetracycline- and ciprofloxacin-resistant commensal Escherichia coli strains in broiler chickens and farm environments, Bangladesh
}

\author{
Avijit Das(D), Pangkaj Kumar Dhar(D), Avijit Dutta(D), Mohammad Shah Jalal(D, Priya Ghosh(D), Tridip Das(D), Himel Barua (D) \\ and Paritosh Kumar Biswas (iD
} Department of Microbiology and Veterinary Public Health, Chattogram Veterinary and Animal Sciences University,
Khulshi, Chattogram, Bangladesh.

Corresponding author: Pangkaj Kumar Dhar, e-mail: pangkaj23@gmail.com

Co-authors: AD: vdr.avijit@gmail.com, ADu: avijitduttadvm@gmail.com, MSJ: shah.jalal.baty@gmail.com,

PG: vdr.priya@gmail.com, TD: das.vet671@gmail.com, HB: himel.barua@gmail.com, PKB: biswaspk2000@yahoo.com

Received: 13-05-2020, Accepted: 24-09-2020, Published online: 10-11-2020

doi: www.doi.org/10.14202/vetworld.2020.2395-2400 How to cite this article: Das A, Dhar PK, Dutta A, Jalal MS, Ghosh P, Das T, Barua H, Biswas PK (2020) Circulation of oxytetracycline- and ciprofloxacin-resistant commensal Escherichia coli strains in broiler chickens and farm environments, Bangladesh, Veterinary World, 13(11): 2395-2400.

\begin{abstract}
Background and Aim: The emergence of antimicrobial resistance (AMR) in commensal organism, such as Escherichia coli of food animals, is an alarming issue for global health. It increases the possibility of transmitting AMR determinant(s) to human bacterial pathogens by transferable genetic materials, particularly by plasmids. Hence, it is important to know which resistant genes are being carried by commensal organisms in food chain in a country and their level of temporal loads. As a result, pre-emptive measures can be advocated with an aim to reduce their risks in their primary source of circulation which consequently would benefit the public health.
\end{abstract}

Materials and Methods: Commensal E. coli strains from broiler chickens on randomly selected 30 farms and the farm environments were examined for the frequencies of isolation of resistant strains to oxytetracycline and ciprofloxacin. Five birds were randomly selected from each farm to collect cloacal swab samples (total of 150 samples). Furthermore, a total of 150 environmental samples comprising one each from feed, water, soil, litter, and litter damping site of each farm were screened for the isolation of commensal E. coli strains. Strains thus obtained were initially tested for their resistance to oxytetracycline and ciprofloxacin by Kirby-Bauer disk diffusion method. Oxytetracycline-resistant strains were further screened for the presence of resistance determining genes, namely, tet $A$, tet $B$, and tet $C$ by uniplex polymerase chain reactions. Risks associated with the isolation frequency of oxytetracycline- and ciprofloxacin-resistant $E$. coli were also assessed by univariable logistic regression analysis.

Results: The results revealed that all E. coli isolates, regardless of the source of origin, were resistant to oxytetracycline, while 78.4\% (95\% confidence interval [CI] 69.1-85.5\%) showed resistance to ciprofloxacin. All the randomly selected (20) oxytetracycline-resistant strains harbored the tet $A$ gene, whereas tet $B$ and $\operatorname{tet} C$ were reported in three and two isolates, respectively. After univariable analysis, only one variable, that is, strain 1 of broiler chickens compared to two other strains was found to be positively associated with the isolation of ciprofloxacin-resistant E. coli (odds ratio 12.75 [95\% CI 1.0 157.1], $\mathrm{p}=0.047)$.

Conclusion: Resistance emerged against oxytetracycline and ciprofloxacin in commensal E. coli strains circulating in live poultry and farm environments in Bangladesh seems to be very high. Thus, human infection with drug-resistant $E$. coli strains through food chain will critically compromise the therapeutic measures currently available.

Keywords: antimicrobial resistance, Escherichia coli, farm environment, poultry.

\section{Introduction}

Antimicrobial resistance (AMR) is now considered as one of the three greatest threats to public health globally. Antibiotic-resistant organism has the potential to affect any species (both animal and human), of any age, in any country [1]. One of the main causes of the emergence of AMR in both pathogenic and commensal bacteria is the indiscriminate

Copyright: Das, et al. Open Access. This article is distributed under the terms of the Creative Commons Attribution 4.0 International License (http://creativecommons.org/licenses/by/4.0/), which permits unrestricted use, distribution, and reproduction in any medium, provided you give appropriate credit to the original author(s) and the source, provide a link to the Creative Commons license, and indicate if changes were made. The Creative Commons Public Domain Dedication waiver (http://creativecommons.org/ publicdomain/zero/1.0/) applies to the data made available in this article, unless otherwise stated. use of antibiotics in food animals. In Bangladesh, antimicrobials are being widely used in food animals, particularly in poultry for prophylaxis and therapeutic purposes [2]. Some poultry farmers consider that using one or more antibiotics at different ages of birds is a routine program of poultry rearing and they do so. These unnecessary usages of antibiotics might have roles in the emergence of AMR in commensal bacteria, such as Escherichia coli, of poultry. This emergence of drug resistance in commensal E. coli of poultry is an important issue to describe as they can be easily transmitted to human, through food chain, as poultry is the easily available protein source throughout the world. Furthermore, the antimicrobial-resistant $E$. coli has the potential to transfer the AMR determinants to other closely related bacterial 
pathogens by transferrable genetic elements, such as plasmids.

Over the years, researchers have reported the emergence of plasmid-mediated resistance in animal origin E. coli against many key antimicrobials including third-generation cephalosporins [3-6] and their transmission from animals to human through food chain or husbandry practice $[7,8]$. For an example, poultry workers in the United States were significantly more likely to carry E. coli resistant to gentamycin, an antibiotic of limited human use than community controls who were not involved with poultry production [9]. Poultry farmers had a higher prevalence of carriage of ciprofloxacin-resistant E. coli $(17 \%)$ than subjects participating in other studies $(<1-3 \%)$ in the 1990s [5]. Once antimicrobial-resistant E. coli are available in the environment, migratory birds, wild animals, and invertebrates, they may further contribute to the dispersal of AMR genes [10,11]. Such strains can also gain entrance to food and water sources along with the final poultry products or indirectly by certain practices of the farm owners, such as selling of the poultry litter as biofertilizer or disposing of poultry wastes and litter into water bodies.

The aim of the present study was designed to assess the frequency and distribution of $E$. coli strains isolated from live broiler chickens and their farm environment that had acquired resistance to oxytetracycline and ciprofloxacin. Screening for the presence of some of the predominant genes determining oxytetracycline resistance was also carried out and risks associated with the isolation frequency of oxytetracycline- and ciprofloxacin-resistant strains were further evaluated.

\section{Materials and Methods}

\section{Ethical approval}

All the applicable ethical guidelines for animal were followed during handling and sample collection from birds and adequate measures were taken to minimize pain or discomfort of selected birds. This project was approved by the ethical committee of Chittagong Veterinary and Animal Sciences University, Bangladesh.

\section{Sampling, study period and location}

A cross-sectional survey was done with sampling of broiler chickens on 30 farms randomly selected from the district of Chittagong, Bangladesh, and their environments. The minimum sample size required for the birds and the farm environment each to be screened was 100 based on the formula $\pi(1-\pi) /$ $\mathrm{e} 2$, where $\pi$ is the prevalence and e is the standard error [12]. We presumed that the prevalence of birds or farm environment with commensal $E$. coli strain resistant to either oxytetracycline or ciprofloxacin was 0.5 with standard error of 0.05 . Therefore, the minimum sample size required for each category (birds or farm environment) was 100 . However, we sampled 150 live broiler chickens on the selected farms and 150 environmental samples comprising 30 each belonging to feed, water, soil, litter, and litter damping site. A two-stage approach: Random sampling of 30 farms followed by random sampling of five birds from each farm and five environmental samples from each of the selected farm was performed between January and June 2017. Cloacal swabs were taken with sterile swabs from the live birds while five swabs collected from each of the environmental sites of a farm were pooled into Stuart's transport medium and shipped to the laboratory for bacteriological investigations.

\section{Isolation and identification of $E$. coli}

For isolation of $E$. coli from a collected sample, the sample was at first inoculated into a test tube containing buffer peptone water (Oxoid Ltd., Basingstoke, Hampshire, UK) and incubated at $37^{\circ} \mathrm{C}$ overnight for primary enrichment. The overnight culture was streaked on MacConkey agar medium (Oxoid Ltd., Basingstoke, Hampshire, UK) and incubated at $37^{\circ} \mathrm{C}$ for $24 \mathrm{~h}$. Bright pink-colored large colonies yielded on to MacConkey agar plate were suspected as the growth of E. coli. Such colonies were streaked onto EMB agar plate (Oxoid Ltd., Basingstoke, Hampshire, UK) and incubated at $37^{\circ} \mathrm{C}$ for $24 \mathrm{~h}$. Based on "green metallic sheen," colony yielded on this medium was taken as the growth of $E$. coli, which was later confirmed by applying standard biochemical tests recommended for the identification of E. coli.

\section{Screening resistance of $E$. coli}

Sensitivity patterns of E. coli isolated to oxytetracycline and ciprofloxacin were tested using disk diffusion method according to the method described by Kirby-Bauer [13] method and the results were interpreted according to Clinical and Laboratory Standard Institute [14] guidelines.

\section{Detection of three tet genes in the oxytetracy- cline-resistant strains}

Strains of $E$. coli that showed resistance to oxytetracycline were recultured on blood agar. DNA from a culture on blood agar was extracted using the conventional boiling method [15]. Specific primer sequences for amplification of tet $A$, tet $B$, and tet $C$ were used as reported before [16]. A thermocycler (Applied Biosystems, Singapore) was used for amplification of DNA. The polymerase chain reaction products were visualized under UV transilluminator (BDA digital, Biometra GmbH, Germany) after gel electrophoresis using $1.5 \%$ agarose gel.

\section{Statistical analysis}

The data were entered into a spreadsheet program of Microsoft Excel 2010 and transferred to STATA 11 (StataCorp, College Station, Texas, USA) for data summary and analysis. To estimate the strength and statistical significance of association of a variable with the isolation frequency of oxytetracycline- and ciprofloxacin-resistant $E$. coli, univariable logistic regression analysis was done. An association was considered significant if a variable had $\mathrm{p}<0.05$. 


\section{Results}

\section{Prevalence of $E$. coli}

Of the 150 cloacal samples investigated, 89 (59.3\%; 95\% confidence interval [CI] 51.3-66.9\%) yielded E. coli. Regardless of sources, on the other hand, 38\% (95\% CI 30.6-46\%) environmental samples tested positive for $E$. coli. Among the environmental samples, the isolation frequency of $E$. coli was higher in litter samples compared with others. An overview of the numbers of samples collected from the 30 selected broiler farms and their environments along with the isolation status of E. coli are shown in Table-1.

\section{Antibiotic resistance}

All the isolates tested showed resistance to oxytetracycline while 78.4\% (95\% CI 69.09-85.45\%) showed resistance to ciprofloxacin. However, the strains isolated from the cloacal samples of the live birds had a higher resistance profile to ciprofloxacin compared with the strains obtained from the farm environment. $E$. coli strains as obtained from different sources and tested for their resistance profiles to oxytetracycline and ciprofloxacin are depicted in Table-2.

\section{Detection of three tet genes (tetA, tetB, and tetC)}

All the 20 randomly selected $E$. coli isolates showing resistance to oxytetracycline harbored the

Table-1: An overview of total samples collected from the selected broiler farms and their environments with the positivity of Escherichia coli.

\begin{tabular}{lccc}
\hline $\begin{array}{l}\text { Name of } \\
\text { sample }\end{array}$ & $\begin{array}{c}\text { Number of } \\
\text { sampled }\end{array}$ & $\begin{array}{c}\text { Positivity } \\
\text { (\%) }\end{array}$ & 95\%; CI \\
\hline $\begin{array}{l}\text { Live bird } \\
\text { (cloacal swab) }\end{array}$ & 150 & $89(59.3)$ & $51.3-66.9$ \\
Feed & 30 & $9(30)$ & $16.52-48.2$ \\
Water & 30 & $11(36.7)$ & $21.81-54.55$ \\
Soil & 30 & $10(33.3)$ & $19.13-51.32$ \\
Liter & 30 & $16(53.3)$ & $36.14-69.77$ \\
Liter dumping & 30 & $11(36.7)$ & $21.81-54.55$ \\
site & & & \\
\hline
\end{tabular}

$\mathrm{CI}=$ Confidence interval tet $A$ gene $(502 \mathrm{bp})$, while three had the tet $B$ gene (930 bp) and two had the tetC gene ( $888 \mathrm{bp}$ ) (Table-3). Isolates resistant to oxytetracycline and having the tet $A$, tet $B$, and tet $C$ genes, as measured by the typical amplicon sizes of the gene products, are portrayed in Figures-1-3, respectively.

\section{Risks factors associated with $E$. coli displaying resis- tance to ciprofloxacin and oxytetracycline}

The results of univariable analyses to assess the risks associated with the isolation frequencies of oxytetracycline- and ciprofloxacin-resistant $E$. coli are shown in Tables-4 and 5, respectively. None but only one variable, that is, broiler strain I compared with other two strains of birds screened had a higher frequency of isolation of E. coli possessing resistance to ciprofloxacin. However, no variables were associated with the higher or lower frequency of isolation of $E$. coli having resistance to oxytetracycline.

\section{Discussion}

Little is known on the circulation of commensal E. coli strains that have acquired resistance to commonly used antimicrobials in poultry in Bangladesh. The results of the survey revealed that all the strains as obtained from the survey were resistant to oxytetracycline. The isolation frequencies of the strains resistant to ciprofloxacin from live broilers, feed, and water used for them and used litter were also alarmingly high. These commensal $E$. coli strains can pass on their resistance traits vertically and horizontally by transferable genetic materials to other enteric pathogens, such as Salmonella [17]. Because ciprofloxacin is one of the critically important antimicrobials to treat enteric fever and other infections in humans in Bangladesh, circulation of $E$. coli strains resistant to this antimicrobial might have a significant public health impact indirectly [18].

Table-2: Escherichia coli strains isolated from different sources and their resistant profiles against oxytetracycline and ciprofloxacin.

\begin{tabular}{|c|c|c|c|c|c|}
\hline \multirow[t]{2}{*}{ Source of sample } & \multirow{2}{*}{$\begin{array}{l}\text { Number of } \\
\text { strain tested }\end{array}$} & \multicolumn{2}{|c|}{ Oxytetracycline } & \multicolumn{2}{|c|}{ Ciprofloxacin } \\
\hline & & Resistant isolates (\%) & $95 \% \mathrm{CI}$ & Resistant isolates (\%) & $95 \%$ CI \\
\hline Live bird & 40 & $40(100)$ & $89.6-100$ & $35(87.5)$ & $73.42-95.01$ \\
\hline Feed & 9 & $9(100)$ & $65.54-100$ & $6(66.7)$ & $35.09-88.27$ \\
\hline Water & 11 & $11(100)$ & $69.98-100$ & $9(81.8)$ & $51.15-96.01$ \\
\hline Soil & 10 & $10(100)$ & $67.91-100$ & $3(30)$ & $10.33-60.77$ \\
\hline Liter & 16 & $16(100)$ & $77.31-100$ & $14(87.5)$ & $62.72-97.76$ \\
\hline Liter dumping site & 11 & $11(100)$ & $69.98-100$ & $9(81.8)$ & $51.15-96.01$ \\
\hline
\end{tabular}

$\mathrm{CI}=$ Confidence interval

Table-3: Detection of tet $A$, tet $B$, and tetC genes in randomly selected isolates showing resistance to oxytetracycline.

\begin{tabular}{lcccc}
\hline Antimicrobial agent & Number of isolates & Gene tested & Positive isolates (\%) & 95\% CI \\
\hline \multirow{3}{*}{ Oxytetracycline } & \multirow{2}{*}{20} & TetA & $20(100)$ & $81.02-100$ \\
& & TetB & $3(15)$ & $4.39-36.88$ \\
& & TetC & $2(10)$ & $1.57-31.32$ \\
\hline
\end{tabular}

$\mathrm{CI}=$ Confidence interval 


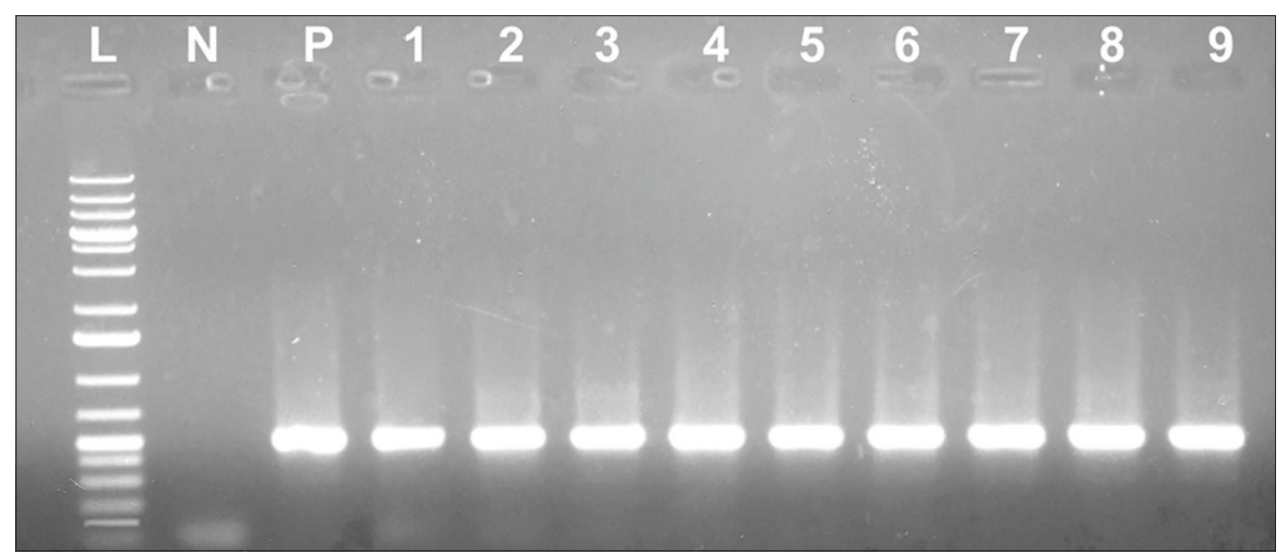

Figure-1: Result of polymerase chain reactions assay for the tetA gene of some of the isolates tested; lane L: $1 \mathrm{~kb}$ plus DNA ladder; lane N: Negative control; lane P: Positive control; lane 1-9: tetA gene sized (502 bp) amplicon.

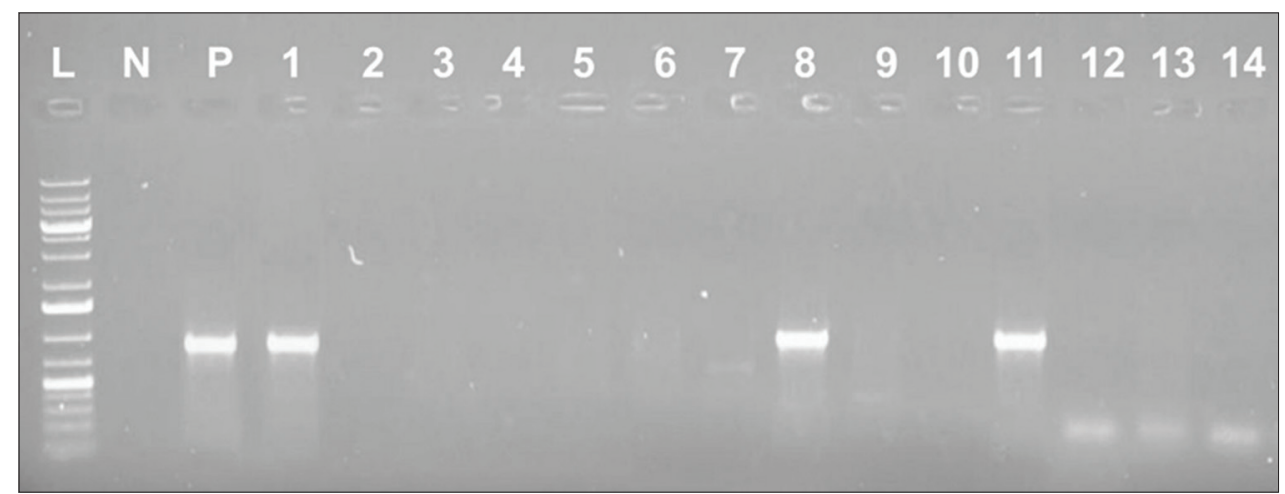

Figure-2: Result of polymerase chain reactions assay for the tetB gene of some of the isolates tested; lane L: $1 \mathrm{~kb}$ plus DNA ladder; lane N: Negative control; lane P: Positive control; lane 1-14: tetB gene sized (930 bp) amplicon.

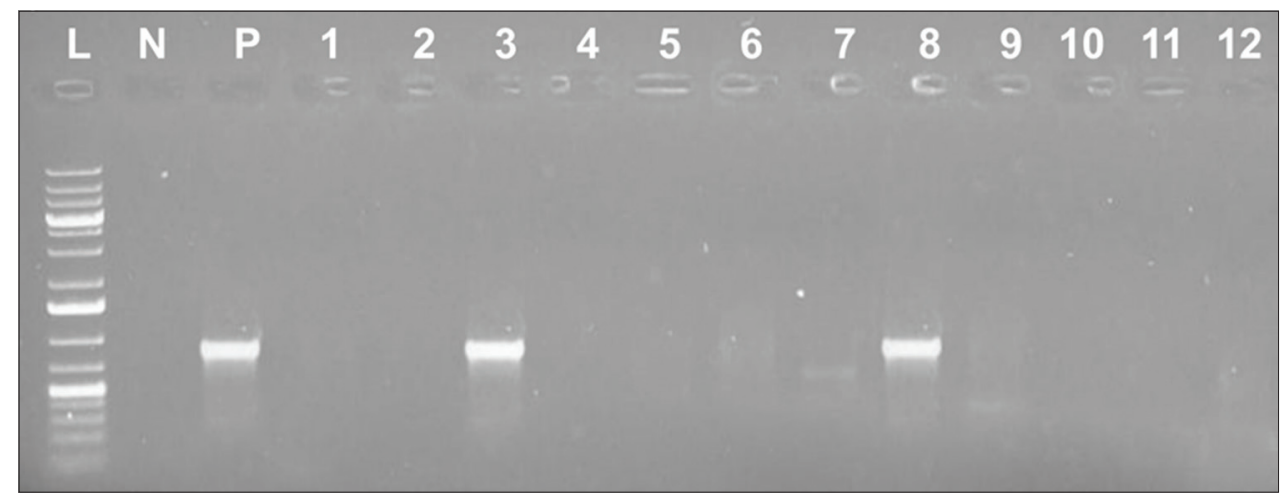

Figure-3: Result of polymerase chain reactions assay for the tetC gene of some of the isolates tested; lane L: $1 \mathrm{~kb}$ plus DNA ladder; lane N: Negative control; lane P: Positive control; lane 1-12: tetC gene sized (888 bp) amplicon.

In this study, all the isolates showed resistance against oxytetracycline (100\%). The result is agreed with a previous study finding, where most of the poultry E. coli isolates were found to be resistant to oxytetracycline $[19,20]$. We found a high resistance pattern of E. coli isolates against ciprofloxacin $(78.45 \%)$, which is, however, not corroborated with the previous findings [21]. This increased resistance to ciprofloxacin over time might be due to sustained and overuse of ciprofloxacin in poultry industry in Bangladesh [20,22].

None of the variables assessed in the study had any independent association with the isolation frequency of commensal $E$. coli acquiring resistance to either oxytetracycline or ciprofloxacin, although after univariable analysis, the frequency of the isolation of E. coli resistant to ciprofloxacin from one of the strains of the birds was significantly higher compared to two others. Therefore, again, sustained overuse or misuse of ciprofloxacin in this strain could not be ruled out for the emergence of resistant strains to ciprofloxacin and their wider circulation.

Tetracycline is a broad-spectrum antibiotic that prevents protein synthesis of bacteria by preventing aminoacyl-tRNA from binding to the ribosome. Resistance to the antibiotic is conferred by one or more of the 36 reported tet genes, which encode one of three 
Table-4: Results of univariable analysis to assess the risks associated with the frequency of isolation of commensal Escherichia coli showing resistance to ciprofloxacin.

\begin{tabular}{|c|c|c|}
\hline Variable & Odds ratio $(95 \% \mathrm{CI})$ & p-value \\
\hline \multicolumn{3}{|l|}{ Source of DOC } \\
\hline Breeder farm 1 & $1.38(0.18-10.7)$ & 0.760 \\
\hline Breeder farm 2 & $0.17(0.009-2.82)$ & 0.214 \\
\hline Breeder farm 4 & Omitted & - \\
\hline Breeder farm 5 & - & Reference \\
\hline \multicolumn{3}{|l|}{ Strain of bird } \\
\hline Strain 1 & $12.75(1.0-157.140)$ & 0.047 \\
\hline Strain 2 & $4.5(0.25-80.577)$ & 0.307 \\
\hline Strain 3 & - & Reference \\
\hline \multicolumn{3}{|l|}{ Age } \\
\hline $1^{\text {st }}$ week & - & Reference \\
\hline $2^{\text {nd }}$ week & $1.7(0.07-37.7)$ & 0.748 \\
\hline $3^{\text {rd }}$ week & $3(0.14-64.26)$ & 0.482 \\
\hline $4^{\text {th }}$ week & $3(0.12-73.64)$ & 0.501 \\
\hline $\begin{array}{l}\text { Use of antibiotics in } \\
\text { the } 1^{\text {st }} \text { week }\end{array}$ & $0.40(0.04-4.02)$ & 0.431 \\
\hline $\begin{array}{l}\text { Use of antibiotics in } \\
\text { the } 2^{\text {nd }} \text { week }\end{array}$ & $1.14(0.23-5.46)$ & 0.873 \\
\hline $\begin{array}{l}\text { Use of antibiotics in } \\
\text { the } 3^{\text {rd }} \text { week }\end{array}$ & $0.94(0.194-4.52)$ & 0.936 \\
\hline $\begin{array}{l}\text { Use of antibiotics in } \\
\text { the } 4^{\text {th }} \text { week }\end{array}$ & $1.4(0.22-8.76)$ & 0.719 \\
\hline \multicolumn{3}{|l|}{$\begin{array}{l}\text { Commercial feed } \\
\text { from }\end{array}$} \\
\hline Producer 1 & - & Reference \\
\hline Producer 2 & $1.1(0.142-8.67)$ & 0.920 \\
\hline Producer 3 & $0.11(0.006-1.77)$ & 0.120 \\
\hline Producer 4 & $1(0.06-15.98)$ & 1.00 \\
\hline \multicolumn{3}{|l|}{ Litter used for } \\
\hline Aquaculture & - & Reference \\
\hline Crop agriculture & $0.29(0.02-3.67)$ & 0.342 \\
\hline $\begin{array}{l}\text { Liquid waste from } \\
\text { farm }\end{array}$ & - & \\
\hline $\begin{array}{l}\text { Drained to open } \\
\text { farm land }\end{array}$ & $0.3(0.03-4.19)$ & 0.395 \\
\hline $\begin{array}{l}\text { Collected by other } \\
\text { people }\end{array}$ & $0.2(0.017-2.26)$ & 0.194 \\
\hline $\begin{array}{l}\text { Drained to } \\
\text { sewerage system }\end{array}$ & - & Omitted \\
\hline $\begin{array}{l}\text { Drained to pond or } \\
\text { for other use }\end{array}$ & - & Reference \\
\hline
\end{tabular}

mechanisms of resistance: An efflux pump, a method of ribosomal protection, or direct enzymatic inactivation of the drug [23]. Efflux mechanisms appear to be more abundant among Gram-negative bacteria, while ribosomal protection mechanisms are more common among Gram-positive. The rapid spread of tetracycline resistance among bacteria is due to the localization of tet genes on transferrable genetic elements such as plasmids, transposons, and integrons [24].

The acquisition of tet $A$ gene in all of $E$. coli isolates showing resistance to oxytetracycline suggests that this gene is predominantly responsible for oxytetracycline resistance and it might has been transferred from the resistant strain to the susceptible one [25]. The contributions of other two genes, tet $\mathrm{B}$ and tet $\mathrm{C}$, might be little. However, due to resource limitation, the presence of other tet genes in the resistant straits was not investigated.
Table-5: Results of univariable analysis to assess the risks associated with the frequency of isolation of commensal ciprofloxacin-resistant Escherichia coli showing resistance to oxytetracycline.

\begin{tabular}{|c|c|c|}
\hline Variable & Odds ratio $(95 \% \mathrm{CI})$ & p-value \\
\hline \multicolumn{3}{|l|}{ Source of DOC } \\
\hline Breeder farm 1 & $2.99(0.14-32.53)$ & 0.570 \\
\hline Breeder farm 2 & - & Omitted \\
\hline Breeder farm 4 & - & Omitted \\
\hline Breeder farm 5 & - & Reference \\
\hline \multicolumn{3}{|l|}{ Strain of bird } \\
\hline Strain 1 & $3.17(0.21-46.73)$ & 0.401 \\
\hline Strain 2 & - & Omitted \\
\hline Strain 3 & - & Reference \\
\hline \multicolumn{3}{|l|}{ Age } \\
\hline $1^{\text {st }}$ week & - & Reference \\
\hline $2^{\text {nd }}$ week & $1.0(0.05-19.34)$ & 1.00 \\
\hline $3^{\text {rd }}$ week & $1.57(0.08-29.40)$ & 0.762 \\
\hline $4^{\text {th }}$ week & - & Omitted \\
\hline $\begin{array}{l}\text { Use of antibiotics } \\
\text { in the } 1^{\text {st }} \text { week }\end{array}$ & - & - \\
\hline $\begin{array}{l}\text { Use of antibiotics } \\
\text { in the } 2^{\text {nd }} \text { week }\end{array}$ & $0.4(0.03-4.96)$ & 0.476 \\
\hline $\begin{array}{l}\text { Use of antibiotics } \\
\text { in the } 3^{\text {rd }} \text { week }\end{array}$ & $0.34(0.03-4.27)$ & 0.406 \\
\hline $\begin{array}{l}\text { Use of antibiotics } \\
\text { in the } 4^{\text {th }} \text { week }\end{array}$ & $0.7(0.05-8.97)$ & 0.784 \\
\hline \multicolumn{3}{|l|}{$\begin{array}{l}\text { Commercial feed } \\
\text { from }\end{array}$} \\
\hline Producer 1 & - & Reference \\
\hline Producer 2 & $1.83(0.12-27.80)$ & 0.662 \\
\hline Producer 3 & - & Omitted \\
\hline Producer 4 & - & Omitted \\
\hline \multicolumn{3}{|l|}{ Litter used for } \\
\hline Aquaculture & - & Reference \\
\hline Crop agriculture & $0.29(0.02-3.67)$ & 0.342 \\
\hline \multicolumn{3}{|l|}{$\begin{array}{l}\text { Liquid waste from } \\
\text { farm }\end{array}$} \\
\hline $\begin{array}{l}\text { Drained to open } \\
\text { farm land }\end{array}$ & $1.78(0.13-23.52)$ & 0.662 \\
\hline $\begin{array}{l}\text { Collected by } \\
\text { other people }\end{array}$ & - & Omitted \\
\hline $\begin{array}{l}\text { Drained to } \\
\text { sewerage system }\end{array}$ & - & Omitted \\
\hline $\begin{array}{l}\text { Drained to pond } \\
\text { or for other use }\end{array}$ & - & Reference \\
\hline
\end{tabular}

\section{Conclusion}

The resistance to oxytetracycline in commensal E. coli strains circulating in live broiler chickens and their farm environments is probably almost cent percent. Most oxytetracycline-resistant E. coli strains harbor the tetA gene, and resistance in these isolates to oxytetracycline is probably due to acquiring the tet $A$ gene. Not all but more than $50 \%$ E. coli strains circulating in broiler chickens and some key farm environments, such as feed, water, and litter, are also resistant to ciprofloxacin. Mutations in the GyrA and GyrB genes could be the molecular mechanisms for acquiring the ciprofloxacin resistance. The isolation frequency of ciprofloxacin-resistant E. coli strains in the strains of broiler chickens reared is not the same. 


\section{Authors' Contributions}

$\mathrm{AD}$ conceived and designed the work and conducted the fieldwork (sample collection, preservation, and transportation) with PKD, ADu, MSJ, PG, and TD. $\mathrm{HB}$ and $\mathrm{PKB}$ supervised the study. $\mathrm{AD}, \mathrm{PKD}, \mathrm{ADu}$, and MSJ performed laboratory work, statistical analysis, interpreted the data, and drafted the manuscript. $\mathrm{HB}$ and PKB edited and reviewed the manuscript. All authors read and approved the final manuscript.

\section{Acknowledgments}

The study was funded by Advanced Studies and Research, Chattogram Veterinary and Animal Sciences University, Bangladesh. There is no specific grant no. for this study.

\section{Competing Interests} interests.

The authors declare that they have no competing

\section{Publisher's Note}

Veterinary World remains neutral with regard to jurisdictional claims in published institutional affiliation.

\section{References}

1. World Health Organization. (2012) Critically Important Antimicrobials for Human Medicine. Available from: https://www.who.int/foodsafety/areas_work/antimicrobial-resistance/cia/en/. Retrieved on 30-10-2020.

2. Bien, T.L.T., Sato-Takabe, Y., Ogo, M., Usui, M. and Suzuki, S. (2015) Persistence of multi-drug resistance plasmids in sterile water under very low concentrations of tetracycline. Microbes Environ., 30(4): 339-343.

3. Bechashk, S.M., Moradi, G., Mohsenpour, B. and Ramazanzadeh, R. (2019) Prevalence of cefepime-resistant Escherichia coli in Iran: A meta-analysis (2007-2016). Iran. J. Public Health, 48(4): 603.

4. Amador, P., Fernandes, R., Prudêncio, C. and Duarte, I. (2019) Prevalence of antibiotic resistance genes in multidrug-resistant Enterobacteriaceae on Portuguese livestock manure. Antibiotics, 8(1): 23.

5. Aworh, M.K., Kwaga, J., Okolocha, E., Mba, N. and Thakur, S. (2019) Prevalence and risk factors for multi-drug resistant Escherichia coli among poultry workers in the federal capital territory, Abuja, Nigeria. PLoS One, 14(11): e0225379.

6. Pormohammad, A., Nasiri, M.J. and Azimi, T. (2019) Prevalence of antibiotic resistance in Escherichia coli strains simultaneously isolated from humans, animals, food, and the environment: A systematic review and meta-analysis. Infect. Drug. Resist., 12, 1181.

7. Sanjukta, R., Dutta, J.B., Sen, A., Shakuntala, I., Ghatak, S., Puro,A.K., Das, S., Huidrom, S., Dey, T.K., Purkait, D., Dutta,A. and Das, B.C. (2016) Characterization of multidrug-resistant Escherichia coli and Salmonella isolated from food producing animals in Northern India. $17^{\text {th }}$ international congress on infectious diseases. Int. J. Infect. Dis., 45(Supplement 1): 114-115.

8. Lavakhamseh, H., Mohajeri, P., Rouhi, S., Shakib, P., Ramazanzadeh, R., Rasani, A. and Mansouri, M. (2016) Multidrug-resistant Escherichia coli strains isolated from patients are associated with class 1 and 2 integrons. Chemotherapy, 61(2): 72-76.

9. Price, L.B., Graham, J.P., Lackey, L.G., Roess, A., Vailes, R. and Silbergeld, E.K. (2007) Elevated risk of carrying gentamicin resistant Escherichia coli among U.S. poultry workers. Environ. Health Perspect., 115(12): 1738-1742.
10. Grenni, P., Ancona, V. and Caracciolo, A.B. (2018) Ecological effects of antibiotics on natural ecosystems: A review. Microchem. J., 136(January 2018): 25-39.

11. Greig, J., Rajić, A., Young, I., Mascarenhas, M., Waddell, L. and LeJeune, J. (2015) A scoping review of the role of wildlife in the transmission of bacterial pathogens and antimicrobial resistance to the food chain. Zoonoses Public Health, 62(4): 269-284.

12. Kirkwood, B.R. and Sterne, J.A.C. (2003) Essential Medical Statistics. $2^{\text {nd }}$ ed. Blackwell Science, Oxford.

13. Bauer, A.W., Kirby, W.M., Sherris, J.C. and Turck, M. (1966) Antibiotic susceptibility testing by a standardized single disk method. Am. J. Clin. Pathol., 45(4): 493-496.

14. Clinical and Laboratory Standards Institute. (2018) Performance Standards for Antimicrobial Disk and Dilution Susceptibility Tests for Bacteria Isolated from Animals: Approved Standard. $4^{\text {th }}$ ed. Clinical and Laboratory Standard Institute, Wayne, PA, USA.

15. Rakib, T.M., Islam, M.S., Nur-E-Azam, M., Islam, S., Al Faruq, A., Das, T., Akter, L., Hassan, M.M. and Hossain, M.A. (2018) Multidrug resistance pattern of Salmonella Typhimurium isolated from rectal swabs of stray dogs at Chittagong metropolitan area (CMA), Bangladesh. Microbiol. Res. J. Int., 25(4): 1-11.

16. Boerlin, P., Travis, R., Gyles, C.L., Reid-Smith, R., Lim, N.J.H., Nicholson, V. and Archambault, M. (2005) Antimicrobial resistance and virulence genes of Escherichia coli isolates from swine in Ontario. Appl. Environ. Microbiol., 71(11): 6753-6761.

17. Boyd, E.F. and Hartl, D.L. (1997) Recent horizontal transmission of plasmids between natural populations of Escherichia coli and Salmonella enterica.J. Bacteriol., 179(5): 1622-1627.

18. World Health Organization. (2012) Critically Important Antimicrobials for Human Medicine. Available from:https:// www.who.int/foodsafety/areas_work/antimicrobial-resistance/cia/en/. Retrieved on 30-10-2020.

19. Biswas, P.K., Faruque, R., Ahmed, S. and Dey, V.C. (2001) Antibiotic sensitivity pattern of pathogenic Escherichia coli isolated from Fayoumi chicken. Bangladesh J. Microbiol., 18(2): 121-126.

20. Dutta, A., Islam, M.Z., Barua, H., Rana, E.A., Jalal, M.S., Dhar, P.K., Das, A., Das, T., Sarma, S.M., Biswas, S.K. and Biswas, P.K. (2020) Acquisition of plasmid-mediated colistin resistance gene mcr-1 in Escherichia coli of livestock origin in Bangladesh. Microb. Drug. Resist., 26(9): 1058-1062.

21. Rahman, M.A., Samad, M.A., Rahman, M.B. and Kabir, S.M.L. (2004) Bacterio-pathological studies on salmonellosis, colibacillosis and pasteurellosis in natural and experimental infections in chicken. Bangladesh J. Vet. Med., 2(1): 1-8.

22. Hasan, B., Faruque, R., Drobni, M., Waldenstrom, J., Sadique, A., Ahmed, K.U., Islam, Z., Parvez, M.B., Olsen, B. and Alam, M. (2011) High prevalence of antibiotic resistance in pathogenic Escherichia coli from large-and small-scale poultry farms in Bangladesh. Avian Dis., 55(4): 689-692.

23. Sloan, J., McMurry, L.M., Lyras, D., Levy, S.B. and Rood, J.I. (1994) The Clostridium perfringens Tet P determinant comprises two overlapping genes: TetA $(\mathrm{P})$, which mediates active tetracycline efflux, and tetB $(\mathrm{P})$, which is related to the ribosomal protection family of tetracycline-resistance determinants. Mol. Microbiol., 11(2): 403-415.

24. Schmidt, A.S., Bruun, M.S., Dalsgaard, I. and Larsen, J.L. (2001) Incidence, distribution, and spread of tetracycline resistance determinants and integron-associated antibiotic resistance genes among motile aeromonads from a fish farming environment. Appl. Environ. Microbiol., 67(12): 5675-5682.

25. Bryan, A., Shapir, N. and Sadowsky, M.J. (2004) Frequency and distribution of tetracycline resistance genes in genetically diverse, nonselected, and nonclinical Escherichia coli strains isolated from diverse human and animal sources. Appl. Environ. Microbiol., 70(4): 2503-2507. 